Chapman University

Chapman University Digital Commons

Education Faculty Articles and Research

College of Educational Studies

$1-1989$

\title{
Broken Dreams, False Promises, and the Decline of Public Schooling
}

Peter McLaren

Chapman University, mclaren@chapman.edu

Follow this and additional works at: http://digitalcommons.chapman.edu/education_articles

Part of the Curriculum and Social Inquiry Commons

\section{Recommended Citation}

McLaren, P. (1989). Broken dreams, false promises, and the decline of public schooling. Journal of Education, 170(1): 41-65.

This Article is brought to you for free and open access by the College of Educational Studies at Chapman University Digital Commons. It has been accepted for inclusion in Education Faculty Articles and Research by an authorized administrator of Chapman University Digital Commons. For more information, please contact laughtin@chapman.edu. 


\section{Broken Dreams, False Promises, and the Decline of Public Schooling}

Comments

This article was originally published in Journal of Education, volume 170, issue 1, in 1989.

Creative Commons License

(c) (i)

This work is licensed under a Creative Commons Attribution 3.0 License.

\section{Copyright}

Trustees of Boston University 


\title{
BROKEN DREAMS, FALSE PROMISES, AND THE DECLINE OF PUBLIC SCHOOLING
}

\author{
Peter McLaren \\ Miami University, Oxford, Ohio
}

The thrust of the most prominent proposals for educational reform in the 1980s has been to make the schools more efficient at servicing the needs of the dominant social order. In the meantime, a backlog of neglected social problems has developed which points up the need for schools to develop the critical faculties of their students. In fact, a wide range of telling statistics on the socio-economic aspects of American education show that the schools themselves are severely impacted by the inequalities present in the larger society-particularly along racial lines. The need for a critical pedagogy is acute.

Schooling in general, and teacher education in particular, have rarely occupied a critical space in contemporary culture. Such endeavors as presently exist are damagingly bereft of both social conscience and social consciousness. The political space that education occupies today continues to de-emphasize the struggle for teacher and student empowerment; furthermore, it generally serves to reproduce the technocratic and corporate ideologies that characterize dominant societies. It is, in fact, reasonable to argue that education programs are designed to create individuals who operate in the interests of the state, whose social function is primarily to sustain and legitimate the status quo. This is not to suggest that critics have not put forth proposals for reforming education programs. The problem has been that when such proposals appear, teaching is often viewed as nearly synonymous with "executing" prefashioned methodologies and "delivering" prepackaged curricula. The absurdity of this position is most evident in the development of programs that some school boards glowingly describe as "teacher-proofed." Teaching thus becomes stripped of its decision-making potential, including its ethical imperative to analyze and remediate existing societal and institutional practices. Teachers are reduced to what Henry Giroux calls "clerks of the empire," whose dreams, desires, and voices are often silenced in order to remove any distractions to industry's call for more entrepreneurial savvy among its future workers,

This is a chapter of the author's newly published book Life in Schools: Introduction to Critical Pedagogy in the Foundations of Education (New York: Longman, 1988). It is reprinted, with minor editing, by permission of the publisher.

A special thanks to Henry Giroux for his reading of this article. This article is greatly indebted to his work. 
and its desire for a more compliant, devoted, and efficient workforce. This image of the teacher is frighteningly similar to the one promulgated in our colleges of education. There, an undue emphasis is placed on training teachers to be managers and implementers of preordained content, and on methods courses that rarely provide students with an opportunity to analyze the ideological assumptions and underlying interests that structure the way teaching is taught.

When teachers, in their acceptance of the role of technicians, fail to challenge the ways in which educational curricula correspond to the demands of industry or the means by which schooling reproduces existing class, race, and gender relations in our society, they run the risk of transmitting to disadvantaged students the message that their subordinate roles in the social order are justified and inviolable. We are unable, then, to assist students in determining how certain individuals, because of their race, class, gender, or social status, come to be positioned favorably or unfavorably within larger sociopolitical relations. For teachers of students who inhabit subordinate positions within society, and for teachers of economically disadvantaged students especially, this apolitical approach to teaching reflects an inability to take a stand on matters of equality and social justice. Such a pedagogical absence turns many inner-city schools into prisons for those students whose parents can't buy them into learning institutions for the more socially privileged. And it turns more affluent schools into educational enclaves for the few, guardians of the status quo.

\section{The Illusion of Education in an Age of Decline}

As I write on the anniversary of the slaying of Martin Luther King, Jr., whose birthday was rescinded as a state holiday by the governor of Arizona, ${ }_{1}^{1}$ reports of growing racial unrest rattle the airwaves. Images of violence in Howard Beach, New York and the shrouded spectres of Ku Klux Klansmen leading demonstrations in Forsyth County, Georgia appear ominously across the television screens of America. For me, these scenes have a sense of deja vu. I am startled by a news clip showing six camouflaged Tennessee Army National Guardsmen breaking from the bowels of a U.S. Army chopper and charging, rebel-style, into a local high school auditorium during a student assembly, mounting a platform near the stage, wild tongues of fire flicking from their $M-16$ s. Surprised by the mock raid and the near deafening gunfire (which turned out to be blank rounds), the students nevertheless respond with unflinching enthusiasm to the Sergeant Major's crisp address:

This morning, shortly after dawn, as we lifted off from Eagle Support Base deep in our territory, we received orders directing us to this location. It seems that an airborne aggressor force had plans to attack this auditorium at 10:00 
this morning. And I guess you heard what happened outside just a moment ago. Guys and girls, this is just a scenario; it's not for real. The weapons are real, the uniforms are real, the helicopter is real, the soldiers are real, but the bullets are not real. . . Almost every continent has war. Almost every continent has people destroying governments. . . Today the ball is in your court. If you are not willing to. . . pick up the weapons of war and defend... this American way of life...then the future America may be like other nations in Central America, South America, the Orient, the Middle East, the Far East. We cannot let that happen in America! ${ }^{2}$

The speech was followed by a terse, "Bravo Company" style command to all those who love America to raise their fists and shout "Hurrah!" Perhaps this event seems too isolated-if not too ludicrous-to be viewed with the same concern as racism and violence in the streets; the Guardsmen had staged their mock raid "lesson" on patriotism, with its portentous millenarian pitch, in only 18 schools. Yet I cannot divorce such coldwar ideology from other forms of "entertainment" so prevalent here in the theaters of this Midwestern town where I now live and teach. Here, as in so many other university towns, sizable numbers of students swaddled in Greek insignia flock to see the likes of Rambo, Iron Eagle, White Nights, Top Gun, Born American or a karate-chopping Chuck Norris rescuing America from hirsute mobsters or Viet Cong infidels. The confluence of patriotism and market strategy occurs in such an orgy of self-assertion that students are unable to evaluate the implications of their ideological allegiance. Here, students inhabit a world of designer identities and regimented desire that transforms forms of difference and improvised community into indicators of deviance.

My conscience obliges me to contrast this situation and the peremptory, authoritarian, and cultural despotism it reflects, with a recent report by the Children's Defense Fund that claims that the United States is one of the worst places to be born in the industrialized world, with 10.8 infant deaths for every 1,000 live births in $1984 .^{3}$ One cannot help but morally recoil upon reading that "A black infant born within five miles of the White House... is more likely to die in the first year of life than an infant born in Third World countries like Trinidad." ${ }^{4}$ Could it be that the most dangerous enemies of America are the gods of expansion, progress, and accumulation, and not some dark and scheming superpowers surreptitiously poised to strike from a distant hemisphere?

We inhabit a perilous course in history in which democracy is in retreat. Many of the gains made during previous decades in social and educational reform have been abandoned or at the very least have demonstrably waned. Not only have we sadly witnessed the delegitimization of the egalitarian impulses of the last two decades, but we have seen an inordinate stress placed on career motivation and school/business partnerships in efforts to link youth to the corporate imperatives of the international marketplace. 
In this age of historical amnesia, endlessly deferred hope, and a retreat from civil rights, the concepts of social struggle and civic courage have congealed around politically accommodating forms of liberal humanism and an ideological shift toward the conservative New Right. As the pillars of our democratic temple wobble in current reactionary winds, we can only glimpse through the cracks of history an uncertain future.

The civil rights marches in Selma, Alabama and other parts of the South, and the fight for daycare programs and community schools, now seem consigned to a museum of memories, historical artifacts of a strange and uncomfortable past. Little has been accomplished beyond the palliative to build upon the democratization of our schools and to ensure the welfare of our nation's youth. Freedom and equality have become dust-covered relics in history's warehouse. Since the aborted cultural revolution of the 1960s, we seem more like curators of old dreams, archivists of history who arrange the past in glass-enclosed dioramas. We have turned into disembodied repositories of reformist visions, shelved in moments of cynical despair, rather than active agents of new communities of risk and resistance.

The ideological shift that characterizes schooling in the last 10 years has hardly been subtle. We need only witness recent attempts by New Right reformists to construct an unproblematic view of history in which schools are called upon to assume their roles as the gatekeepers of society by passing on the great tradition of old-fashioned "republican virtues" embodied, for example, in books such as the McGuffey readers and in the old Latin classics curriculum. In fact, the image of the public school put forward by exponents of the New Right approximates a mixture of the fundamentalist Sunday School, company store, and "old West" museum. 5 The dominating logic of this agenda is bolstered by arguments put forward by individuals such as Gary L. Bauer, Undersecretary of Education, who blames America's "youthful fling with self-indulgence" during the 1960s and 1970s for the current malaise in American society. ${ }^{6}$ This view is less than convincing when promulgated by representatives of a government that is performing terrorist acts against governments in Central America, trading in arms with Iran, and eroding the call for civic courage and critical citizenship in our public schools?

Today's students have inherited an age in which liberty and democracy are in retreat. Ironically, existing criticisms of schooling and the agenda for educational reform themselves constitute part of this retreat. On the one hand, neo-conservatives have defined the school as an adjunct of the labor market, couching their analysis in the technocratic language of human capital theory. On the other hand, liberals have provided a more comprehensive critique of schooling, but so far have been incapable of addressing the major problems that schools face within a race-, class-, and gender-divided society. The resulting prescriptions for school reform are severely restricted. 
In the present rush toward accountability schemes, corporate management pedagogies, and state-mandated curricula, an ominous silence exists regarding the ways in which new attempts to streamline teaching represent an attack on both the democratic possibilities of schooling and the very conditions that make critical teaching possible.

Framed in the language of hypernationalism and supply-side economics, the current conservative attack on schools represents, in large part, a truncation of the democratic vision. Underlying the new reform proposals set forth by the recent coalition of conservatives and liberals is an attack on schools for producing a wide-ranging series of national crises, ranging in scope from the growing trade deficit to the breakdown of family morality. Not only does such an attack misconstrue the responsibility schools have for wider economic and social problems, but it is characteristic of a dangerous ideological shift that has been taking place regarding the role that schools should play in relation to the wider society.

At the heart of the ideological shift is an attempt to define academic success almost exclusively in terms of capital accumulation and the logic of the marketplace. The authors of the new "blue ribbon" committee reports have cast their recommendations in a language that reflects the resurgence of chauvinistic patriotism and have reformulated their goals along elitist lines. ${ }^{8}$ In doing so, they have attempted to eliminate a social concern for nurturing a critical and committed citizenry. They have passively surrendered educational reform to a fetishism of procedure rather than demonstrating a concern with social goals. Furthermore, the increasing adoption of management-type pedagogies has resulted in policy proposals that promote the deskilling of teachers and the creation of a technocratic rationality in which planning and conception are removed from implementation, and the dominant model of the teacher becomes that of the technician or white-collar clerk. At the same time, the model of the school has been transformed, in Giroux's terms, into that of the "company store." In general, the new efficiency-smart and conservative-minded discourse encourages schools to define themselves essentially as service institutions charged with the task of providing students with the requisite technical expertise to enable them to find a place within the corporate hierarchy.

This New Right ideology of school reform provides only a sterile and truncated range of discourses and conceptions which undermines what it means to be a critical citizen. Under the logic of the new reforms, students are taught to link citizenship to the profit imperative and to the norms of market relations and brokerage politics wherein the vested interests of the individual, the corporation, or one's country are always valued over the collective interests of humanity. Rarely is the concept of profit maximization considered immoral, even when it is discovered to be at the expense of the poor or minority groups, or, further afield, at the expense of the social and educational development of Central American and Third World popula- 
tions. Absent from this discourse is any recognition of the importance of viewing schools as sites for social transformation and emancipation, as places where students are educated not only to be critical thinkers, but also to view the world as a place where their actions might make a difference.

Some recent statistics may help guide the reader's attention to the full seriousness of the decline of this particular epoch. In their recent book On Democracy, Joshua Cohen and Joel Rogers provide some startling statistics which at the very least call into question-if not effectively shatter-the larger-than-life braggadocio of pro-American apologists and the quiescence surrounding some longstanding myths of American life. For instance, the common assumption that the American standard of living is the highest in the world has been repeatedly challenged by the Organization for Economic Cooperation and Development, which claims that in 1980 the United States ranked 11th, behind Switzerland, Denmark, Sweden, West Germany, Iceland, Norway, Belgium, Luxembourg, the Netherlands, and France. Diminished expectations exist where once there were endless possibilities. In 1950 nearly $70 \%$ of all American families could afford to buy a house. By 1980, first-time purchase of a home was impossible for $80 \%$ of those who did not already own a home. This means that, unless the situation reverses itself, only about 2 out of every 10 students in our classrooms can look forward to eventually owning their own homes, let alone realizing the dream of the paneled recreation room and the two-car garage. Worker benefits lag far behind those in the rest of the industrialized West. And social spending? As a percentage of the GNP, social spending in America constitutes less than half what it is in West Germany and Sweden. Virtually all advanced nations, including the Netherlands, the United Kingdom, Japan, and France, spend more on social services than does the United States?

In addition to the crisis of social planning and services, there are serious concerns today regarding issues such as the safety of our citizens. Urban dwellers now live in the frightening hypertrophy of an urban frontier populated by gunslingers (usually the exploited poor and ethnic minorities). In fact, in some of our major cities we are in peril of being murdered at a rate 8 or 9 times greater than in other advanced industrial nations. In fact, if one was born and remains a resident of a major city in the United States, one's chances of being murdered are greater than the threat of death in combat experienced by American soldiers in World War II and it may come as little surprise to minority groups that the probability of being murdered for nonwhite men in the United States is 6 times as great as the probability for white men..$^{10}$ For those of us who have actually grown up believing in a free and equal America, the grim news is staggering: with the exception of the Soviet Union and South Africa, the United States has 
a larger percentage of its citizens behind bars than any other country. In fact, a new handgun is sold every 13 seconds in this country. Homicide, coupled with suicide, constitutes the sixth leading cause of death. ${ }^{11}$ Teenage homicide is up more than $200 \%$ since 1960 ; arrests of 18- to 24-year-olds are up from $18 \%$ in 1960 to $34 \%$ in 1980, and young people under 21 account for more than half of all arrests for serious crimes. School vandalism has been estimated by a Senate subcommittee to cost $\$ 500$ million a year. ${ }^{12}$ In 1983, approximately $46 \%$ of all persons sent to prison were black, even though blacks make up only $12 \%$ of the population..$^{13}$ Most of the victims of their crimes were black.

There is little question that American life continues to produce an underclass among many black, Puerto Rican, Chicano, West Indian, and Central American communities concentrated in urban ghettos, in the South Bronx, Spanish Harlem, Roxbury, Watts, and West Town, Chicago, for example, where the violent impact of ghetto conditions is suffered most cruelly. It is here where gang life proliferates. For instance, Los Angeles is home to over 200 gangs, with 187 gang-related homicides in $1986 .{ }^{14} \mathrm{We}$ also know that there has been an explosion of white suburban gangs in places like California, whose middle-class members engage in fights, robberies, and killings. The Los Angeles County Sheriff's Department estimates that there are 1,200 members of white street gangs in Los Angeles County alone.15

We are all familiar with the ecological crisis, having witnessed smog levels in our cities growing by $1,000 \%$ between World War II and the early 1970s. Environmental hazards are, we grudgingly admit, getting worse, as safe drinking water standards are constantly violated and toxic waste dumps continue to leak poisonous chemicals. But we are equally inattentive and inactive when it comes to the estimated 2 to 6 million students and 100,000 to 300,000 teachers who still attend and work in schools with asbestos surfaces. ${ }^{16}$

Increasingly we face reports about widespread drug and alcohol abuse, with the number of alcoholics and problem drinkers in the United States now numbering approximately 13 million, and 1 in every 40 residents of New York City addicted to heroin. ${ }^{17}$ The media has good copy here. Journalists wearing pastel colors and accompanied by television crews join secret vice squad raids on cocaine pushers in a Hollywood-style attempt to add excitement and glamour to the epidemic. Total arrests for drug abuse violations among those under 18 years of age increased 60 -fold between 1960 and $1980 . .^{18}$

As poverty, inequality, and drug addiction blight the nation, we direct our anger not at government policies or the social conditions that manufacture human suffering, but at the arch-villains of communism and socialism. We forget that the lowest fifth of our own population receives a smaller 
percentage of total after-tax income than is true in Japan, Sweden, Australia, the Netherlands, West Germany, the United Kingdom, Norway, Canada, and France. In fact, the gap in real-income level between the bottom quintile of American families and the top $5 \%$ has nearly doubled over the past 30 years. On the one hand, the percentage of wealth held by the top $1 \%$ to $2 \%$ of the population is greater in the United States than in most industrial nations; on the other hand, it remains the case that 1 in every 7 Americans and more than 1 in every 5 children under the age of 6 lives in poverty. ${ }^{19}$

Appearing in tandem with the decimation of low-income housing, growing unemployment, the deinstitutionalization of mental patients, and the rise of alcohol- and drug-related abuses, is the new class of urban homeless. The housing shortage across the United States, coupled with the substantial increase in the poverty population of the cities, has created a new and growing group of vagabond city dwellers who report a wide range of social and personal pathologies. ${ }^{20}$ Many homeless are teenagers coming directly out of foster care and precipitously dumped into the streets without follow-up community support. ${ }^{21}$

There is currently an epidemic of teenage pregnancies $(500,000$ births to girls under 20 in 1983).22 In 1982, 9 out of 10 babies born to black women under the age of 20 were outside of marriage. Teenage pregnancy is up $109 \%$ for whites and $10 \%$ for nonwhites since $19600^{23}$

These are only a few of the available statistics and reports on the crisis in American society, but they should be sobering enough to most Americans to make us aware that we live in a time of drastic social upheaval. Regardless of how we wish to characterize the crisis, the familiar adage seems to hold true: the rich get richer while the poor get poorer.

Other statistics related to youth and schooling have recently been made available by the authors of the highly acclaimed book Choosing Equality. Unfortunately, these statistics do not give us cause to rest any easier. Our school system is revealed as inexorably multitiered, with the children of the working poor held to the lower rung and suffering the most. For example, the authors of Choosing Equality report that $50 \%$ to $80 \%$ of all inner-city students drop out of high school (Chicanos and Puerto Ricans use the more appropriate term "pushed out"|; 1 million teenagers cannot read above the third-grade level; $13 \%$ of all 17 -year-olds are functionally illiterate; $28 \%$ of all students fail to achieve high school diplomas; $50 \%$ of all college entrants drop out in their freshmen year; and 33\% of all adults are described as functionally or marginally illiterate. ${ }^{24}$

It is becoming clear that the consequences of schooling are increasingly dependent on the social class of the child. Radical educators argue that the structural constraints that characterize schooling and the wider society reinforce inegalitarian stratification-that schools are reduced to 
credentializing mechanisms, protected enclaves that favor the more affluent. The "best" schools nurture cocoons of yuppie larvae, facilitating entry of certain students into more privileged locations in the labor market; the worst simply lock the doors to those privileged locations for students already disproportionately disadvantaged. In all, the schools constitute a loaded social lottery in which the dice fall in favor of those who already have money and power.

One index of the persistent refusal of schools to develop a means to empower minority and disadvantaged groups is the widespread practice of tracking students into ability groups. Tracking assumes that schools play a part in meritocratic selection and allocation based on ability. In fact, however, tracking fosters the illusion of meritocratic competition while in reality functioning as a "ranking" system that legitimates differences based on race, gender, and social power and locks students into positions of limited opportunity. Tracking thus perpetuates social class inequalities through selection and allocation procedures. ${ }^{25}$

Tracking in the United States can be traced to the birth of the comprehensive high school in the early 1900s. ${ }^{26}$ This new type of schooling, made necessary by the influx of unskilled immigrants from southern and eastern Europe and the enforcement of child labor and compulsory education laws, abandoned the principle of presenting a common core of learning to build a cohesive nation. Instead, it emphasized curriculum differentiation in the form of tracking and homogeneous grouping. Social Darwinism provided legitimacy to the notion that ethnic minorities and the poor were lower on the evolutionary ladder and less fit in moral development than the dominant Anglo-Protestant majority. Coupled with a growing concern for preserving the Anglo-Saxon culture against the "depravity" of the expanding immigrant population, Social Darwinism thus provided a foundation for the trend toward "Americanization," which eventually came to dominate the school curriculum.

American industry provided the logic for this new kind of education by presenting schools with the factory model of learning. Production and efficiency became the guiding ideological principles in establishing vocational education as an appropriate alternative for students not bound for college. The development of IQ tests provided a statistical base with which to classify students, although these tests simply reinforced the original classification by racial, ethnic, and economic background. Educational testing, undertaken in the spirit of scientific efficiency, was viewed as meritocratic, since it helped sort students into specialized programs where they would receive what was thought to be the best possible education, given their abilities and the opportunities available to immigrants in the industrial workplace. 
Jeannie Oakes's study Keeping Track illustrates how tracking in American schools alienates students and undermines their social aspirations and feelings of self-worth. Oakes argues that students at the bottom of the social hierarchy adjust their aspirations downward as a result of tracking without being aware that schools are treating them unjustly. In essence, schools play a major role in the legitimization of inequality; that is, in socializing students to accept the unequal features of the larger society. Oakes argues that students who are poor and from a minority background are the most disempowered and disenfranchised by school tracking procedures. This effect derives in part from the way in which school knowledge is distributed within high-track and low-track groups. Students in low-track groups are more likely than others to be from poor and minority backgrounds and to be taught behaviors that will make them suitable for lowstatus jobs. In other words, low-track students are taught low-status knowledge, which has little exchange value in a social or economic sense.

Oakes's data on tracking reveal that students in high-track groups enjoy distinct educational advantages over those in low- and middle-track groups: for the high-track groups, more time is set aside by teachers for learning; more actual class time is spent on learning activities; more attention to homework is expected; fewer students are permitted to be off-task; and more instructional practice is given. In short, for high-track students, learning takes place in an environment that confirms the students' high-track identity, where time, activity, and place are structured so as to encourage their sense of self-esteem and achievement.

For low-track students, time in school may be more a burden than an asset. Such students often view knowledge as unrelated to their lives and instruction as an assault on their time. School becomes a place for enduring "dead time" rather than using it in the interests of self and social empowerment. If such students learn anything, it is in spite of the degradation they endure.

It is safe to assume that the degradation students experience in the lower tracks significantly contributes to the growing instances of dropping out of school. In the United States there are presently 1.1 million 16- to 19-year-olds and 3.3 million 20- to 24-year-olds with less than a high school diploma who are not currently enrolled in school. The proportion of 17 . to 18-year-olds who were not high school graduates increased from about $24 \%$ in 1972 to about $28 \%$ in 1982 . Dropping out is not evenly distributed racially, economically, or geographically. Among 20- to 24-year-olds, the dropout rate proportion for Hispanics is $40.8 \%$, for blacks, $23.2 \%$, for whites, $14.6 \%$. Despite the lower dropout rate for whites, this pattern can be better explained by income than race. For instance, Michael W. Sherridan cites a 1977 study of families with incomes under $\$ 10,000$ that reveals the proportion of white 14- to 17-year-olds who were not enrolled in school 
to be nearly twice as high as for blacks. ${ }^{27}$ High school dropouts are more likely to require a wide range of social services, including welfare, medical assistance, and unemployment assistance. They are more likely to engage in crime, have poorer health, have lower rates of intergenerational mobility, and have lower rates of political participation. As early as 1972, estimated costs throughout the country of providing social services and fighting crime associated with dropping out were $\$ 6$ billion per year. ${ }^{28}$

School systems in the inner city are usually the hardest hit by dropouts, for it is here that the last remnants of real education have been driven out of the process of schooling. Consider the case of New York City. An independent study of public high school dropouts claims that $66 \%$ of all students who attend high school in New York fail to graduate. For Hispanic students, the rate is $80 \%$, for blacks, $72 \%$, and for whites, $50 \%$. Equally alarming is the news that $80 \%$ of teenage mothers and $90 \%$ of all special education students fail to achieve their high school diplomas. ${ }^{29}$

The case of Chicago schools is equally as grim. A recent survey of 44 nonselective, four-year high schools, each with over $50 \%$ black and Hispanic enrollment, revealed that only $39 \%$ of entering freshmen were still in school in their senior year. Of that $39 \%, 41 \%$ were below the ninth grade reading level (the minimum proficiency level), $41 \%$ were at or above ninth grade proficiency but were below the national median for seniors, and only $18 \%$ were finishing high school at or above the national median. In urban school systems in general, only $7 \%$ of those who enter high school graduate with achievement levels equal to $50 \%$ of their peers nationwide.

The chilling reality is that poor and minority youth, who are already receiving substandard schooling, are likely to be left entirely outside the job market. The authors of Choosing Equality point out that:

Working-class youth, who have no particular advantage in their schooling, will not have compensating job or income opportunities as adults. And schools will be increasingly hard-pressed to motivate their students through career aspirations or goals.

Given the disjuncture between economic and educational rewards, the effort to link school reform to the market value of education threatens to abandon large segments of American youth. If one argues that schools should reflect the logic of a polarizing labor market, the necessary conclusion is that we must reinforce competitive schooling-raise elitist barriers, add new stratification mechanisms, reward only the most exceptional or advantaged ${ }^{31}$

The emerging generation with its attendant familial, racial, ethnic, and socio-economic characteristics does not give teachers much cause for optimism. A recent demographic portrait suggests that teachers face a prospect of grimly enormous proportions and ever greater social implications. By September of 1987: $25 \%$ of the childhood population are from families 
who live in poverty; $14 \%$ are children of teenage mothers; $15 \%$ are physically and/or mentally handicapped; another $15 \%$ are non-English-speaking immigrants; $14 \%$ are children of unmarried parents; $40 \%$ live in broken homes before they reach 18 ; and $10 \%$ have illiterate or nearly illiterate parents. And finally, up to $33 \%$ are latchkey children who have no one to look after them during lunch and during the late afternoon, and $25 \%$ of them will not finish high school ${ }^{32}$

The United States is currently facing a growing immigrant population with school systems exceedingly hard-pressed to meet their needs. In the 33 years since Brown vs. Board of Education of Topeka in 1954, schools in the United States have enrolled more linguistic and cultural minorities than ever before. Forty percent of all legal immigrants to the United States are Asian. ${ }^{33}$ The steadily expanding population of Asian Americans, now at 5.1 million, represents $2.1 \%$ of the total population of the United States. Happily, immigrants from Taiwan, the Philippines, South Korea, Japan, Hong Kong, India, and Vietnam - whose native cultures have been credited with highly valuing education as a means to success-have become the country's most upwardly mobile minorities. Asian students average higher on the Scholastic Aptitude Test math scores than any other ethnic group. Furthermore, they take more math, science, and foreign language courses, and spend more hours on homework assignments. ${ }^{34}$

For some time the dominant culture has portrayed Asian immigrants as the "model minority"-a homogeneous community that is uncomplaining, hard-working, highly educated, family-oriented, and financially successful. While this depiction has largely been true, it also masks the complexity of the reality many Asians presently face in American society. Undoubtedly the dominant culture would like other oppressed minorities to link success to the virtues of self-sacrifice and competitiveness, rather than to struggle politically for the redress of social injustices and institutionalized racism. But the face of the Asian minority is changing. The majority of current Asian immigrants are impoverished refugees fleeing war and repression. Unlike the ethnic Chinese from Vietnam, China, Hong Kong, and Singapore, many of whom came from privileged backgrounds in their own countries and arrived in the United States before 1976, Southeast Asian refugees are not urban people, have little or no formal education or previous contact with Western culture, and have no preestablished communities to join..$^{35}$ The immigrants enter the United States, as other immigrants have before them, on the lowest rung of the socioeconomic ladder. In California, approximately $50 \%$ of Indochinese immigrants are on welfare, and a 1980 census revealed more than $35 \%$ of Vietnamese families in the United States living below the poverty line. The dropout rate for Southeast Asian students has increased from 14.4\% in 1982 to $26.5 \%$ in $1985 .{ }^{36}$ 
While Asians are the second fastest growing minority population in the country, and while the mean family income for Asian-American families according to the 1980 U.S. census is $\$ 26,456$ (nearly $\$ 3,000$ higher than for white families), more recent immigrants such as the Hmong, Laotian, Kampuchean/Cambodian, and Vietnamese arriving after 1976 do not mirror the success stories so widely proclaimed in the nation's press.

The stereotyping of Asian students as successful due to the virtues of passivity, industriousness, and conformity not only exhorts other minorities to adopt these nonresistant values and behaviors, but also has prompted a backlash against Asian Americans. There has been a dramatic rise in acts of violence against Asian immigrants, and there is increasing evidence that select universities are designing "hidden quotas" to exclude qualified Asian applicants.

For another $40 \%$ of all legal immigrants-those from Mexico, Central and South America, and the Caribbean-success is less often secured. ${ }^{37}$ These are the students most clearly devalued by intelligence tests that continue to be culturally and linguistically biased in favor of middle-class Anglo-Saxon students. Since the tests are usually administered before the student has had a chance to adapt to North American life, many students understandably score poorly. Yet these scores often become the basis for tracking students into basic-level courses and for sending them to the school psychologist's office. It is wrong to accept the stereotype that every Asian youth is a predestined Merit Scholar, just as it is wrong to consider all blacks and Hispanics irrevocably trapped on the lower rungs of the socio-economic order. There are Asian youth gangs, and Asian students are by no means immune to illiteracy. There are also high-achieving black, Chicano, and Puerto Rican students. Nevertheless, when considering factors such as intelligence, creativity, motivation, and economic prosperity, it remains the case that socio-economic status is the greatest predictor of academic success in the United States. ${ }^{38}$

By $1980,27 \%$ of all public school students in the United States were nonwhite, and the immigrant population has grown substantially since that time. California now has a "majority of minorities" in its elementary schools, while Texas has $46 \%$ black and Hispanic students. ${ }^{39}$ Many of these minority families are supported by a single parent. Nearly every large-city school system has predominantly minority enrollments and large numbers of students whose first language is not English. One study estimates that by the year 2000, 53 major cities will have predominantly immigrant populations. ${ }^{40}$ Presently, however, only $8.5 \%$ of all teachers are minorities. ${ }^{41}$

It is certainly true that many new immigrants find living conditions in the United States an improvement over those in their native lands. It is also true that in the United States there is still a considerable measure of social freedom. For many past and prospective immigrants, the United 
States represents a historically powerful metaphor for what it means to be prosperous and free. It is the ideal of democracy, freedom, and social mobility that attracts a large majority of immigrants. The image of the United States has been both a rationally and an emotionally compelling force on the international stage for many decades. The pervasiveness of this image of America suggests the strength of America's international hegemony. It also suggests the power of the global communications network to shape ideology and, in some cases, to support new modes of domination, and also the capacity of American business and advertising to invade world markets and establish ideological frames of reference for measuring personal success.

We must acknowledge, however, that the real conditions of life experienced by many immigrants in the United States fall short of the ideal. In some cases the United States actually supports the regimes that oppress these people; we offer them only the "choice" between places in which to be poor. ${ }^{42}$ The point, of course, is not to argue about which country has the worst ghettos, but rather to fight to make the principles of equality and justice a greater reality at home.

The fastest growing population in the nation today is Hispanic, including Mexican-Americans, Puerto Ricans, Cuban-Americans, and others. The Hispanic population is by and large young, and it has been hit hard by the erosion of equality in American schooling. While the majority of Hispanics enter high school with educational and career aspirations as high as any other group in our society, $40 \%$ of all Hispanic students drop out before the 10th grade. In addition, $25 \%$ of Hispanics who enter high school are overage. Forty-five percent of Mexican- American and Puerto Rican students who enter high school never finish, compared to $17 \%$ of Anglo students. Hispanics experience an exceptionally high rate of poverty $-38.2 \%$ for youth under 18 , compared to $17.3 \%$ for Anglos. The majority of Hispanics (85\%) live in metropolitan areas concentrated in California, Florida, Illinois, New York, and Texas. Thirty-five percent of Hispanic students are systematically tracked into vocational education programs that do not provide up-to-date training. Forty percent of Hispanic students are slotted into general educational programs as opposed to academic programs. ${ }^{43}$ These are students in drastic need of a critical pedagogy, a new way of viewing schooling, that can enable them to analyze their oppression and to take steps to redress the conditions that perpetuate it.

Of every 100 children born today, 12 are born out of wedlock and 40 are born to parents who will divorce before the child is $13.4^{44}$ Minority children face a particularly tough road ahead of them. A recent report published by the Children's Defense Fund reveals that while 8 out of every 10 white children live in two-parent families, this is the case for only 4 
out of every 10 black children. Thirty percent of black children under the age of 3 live in households headed by someone other than their parents. In addition, studies show that in only a few years 1 black child in 4 will live in a female-headed family. In other words, black children are over $3 \frac{1}{2}$ times more likely than white children to live in female-headed households. ${ }^{45}$

While black children in female-headed families are the poorest in the nation, with a median income of $\$ 8,648$ in 1984 , the problem goes far beyond the poverty problems associated with single parenthood. Black children in two-parent families are twice as likely as white children in twoparent families to live below the poverty line. In fact, almost half of all black children are poor compared to 1 in 6 white children. Black men and women at all educational levels are less likely to be employed than white men and women, and those who are employed earn less than their white counterparts. Nearly 2 out of every 5 black children are growing up in a family whose head did not complete high school, and this is twice the rate for white children. Black students at all ages are poorer readers than whites, less likely than white students to attend college, and are twice as likely to be suspended from school, to be corporally punished, or to be out of school. Six out of ten special placements of white students are in gifted and talented programs whereas only 1 in 10 black students are in special placements in such programs. Equally alarming is the fact that black children are 3 times as likely to be placed in classes for the educable mentally retarded, a reality that carries with it the shame of racism. ${ }^{46}$ Of course, the legacy of racism and inequality can be traced back to an earlier America, where official historians have often carefully overlooked dimensions of American history, especially those subjugated knowledges of marginalized and disenfranchised peoples. Some contemporary sociologists would like to blame the economic condition of blacks on teenage pregnancy, social isolation, or the impoverished aspirations of ghetto blacks who don't come into enough contact with middle-class achievers. Or else they blame the middle-class blacks who have left the ghetto for not staying there as role models for the poorer blacks. These views simply recycle the "blaming the victim" ideology by shifting the blame onto the blacks themselves and deflecting attention away from the structural causes of poverty and racism and the denial to blacks of full participation in the economic system.

Even the academy-the so-called bastion of truth seeking, enlightenment, and tolerance-has become a setting for racist incidents that evoke images of Alabama and Arkansas in the 1950s. Recent incidents at the University of Michigan, Purdue, Northern Illinois, Columbia, and UCLA mark just the surface of a brewing racist cauldron in America. When an unauthorized Northern Illinois University magazine prints sick verse such as "Ok,/look nigger,/we are white/white is supreme/Jesus was white/God is white/All of our presidents have been white/Thank you God $/{ }_{1}^{47}$ we have 
to wonder what the future of higher education holds. When 1,500 students engage in a black versus white brawl at the University of Massachusetts in Amherst, when fraternities try to bar black students from open parties, and when routine residence passes are checked for blacks but not for whites, ${ }^{48}$ we need not deceive ourselves into thinking that racism is a disease that was "cured" during the civil rights movement of the 1960s. Its importunate clamor can be heard today in the ivory tower.

It appears that Jim Crow has been resurrected from the other side of the tracks. Although we are told that blacks are now "making it," it remains the case that discrimination is rampant, and many recent victims are black women. We know, for instance, that more 14- and 15-year-old black women dropped out of high school in $1981(3 \%)$ than 10 years earlier $(1 \%)$ and we know also that blacks of either sex and women of any race are less likely to enroll in an academic high school curriculum than white males. Consequently, it comes as little surprise that black women are disproportionately placed in vocational programs. The percentage of black high school graduates attending college dropped $11 \%$ between 1975 and 1981. Both blacks and women are likely to receive less financial aid than white men, and low-income women received fewer guaranteed student loans than did low-income men. Also, childcare expenses cannot be used in computing need, a restriction that disproportionately affects women. ${ }^{49}$

The American commitment to equality of opportunity is violated at its very roots by the fact that local and state governments continue to pay more for one child's education than for another's. The abiding constants of American education-equality of opportunity and meritocracy-favor existing elites and place minority students in the debt column of the ledger of academic achievement. Since we finance our schools primarily through local property taxes and state revenues (with a lesser amount added by the federal government), and since some states and school districts have significantly more taxable wealth than others, the money spent per student varies significantly from district to district. Some states have tried to provide formulas to promote more state funding for poorer districts, but legislators who know they must represent positions congenial to those who vote for them frequently subordinate these efforts to other concerns designed to win support from constituents in the wealthier districts. ${ }^{50}$ The disparities among schools within a district, strangely, are often just as great as those between low-income urban and rural districts and affluent suburban districts within the same state. Here also the disparity reflects the racial and economic makeup of the school population.1

The myth that local school boards "balance" the special interests of bureaucratic and professional influence in state education policy (accrued by political and business leaders, academic experts, and pressure groups) is shattered when we note the kind of oligarchies represented by some local 
boards, who wield tremendous influence over communities through the allocation of school resources and patronage. The structure and actions of local school boards in the state of Georgia, for example, suggest the barriers that local boards can raise to minority empowerment. Since desegregation was ordered in 1970, the Georgia public schools have been essentially resegregated through the reactionary policies of local school boards. Of 22 Georgia districts with at least $63 \%$ black enrollment, only 2 had majority black school boards. Georgia grand juries still select 40 school boards, and school boards presiding over systems with more than $70 \%$ black students require $50 \%$ less in local property taxes than those with more than $70 \%$ white students. ${ }^{2}$

Lack of funding usually goes hand-in-hand with lack of school resources, competent teachers, and services. Invariably, it is the poor and minority student who is hardest hit by disparities in funding. In a recent report of the Board of Inquiry commissioned by the National Coalition of Advocates for Students, entitled Barriers to Excellence: Our Children at Risk, we discover and lament the following indicators of cultural discrimination: only about $33 \%$ of the estimated 2.7 million limited English proficient students aged 5 to 14 receive any form of special programing responsive to their linguistic needs; in 1980, only $10 \%$ of Hispanic children with limited English proficiency were in bilingual programs; studies conducted in urban high schools have revealed dropout rates as high as $85 \%$ for Native American students and between $70 \%$ and $80 \%$ for Puerto Rican students; large number of textbooks used in classrooms remain culturally biased, both in their presentation of material and in their omission of material on the culture, history, or achievement of many of the national and cultural groups represented in American schools. While nearly $25 \%$ of all public school teachers in the United States had students with limited English proficiency (LEP) in their classes in 1980 and 1981, only $3.2 \%$ of those teachers said that they were equipped to deal with these students. ${ }^{53}$ With statistics such as these, it is hard to dispute the accusation made in the report that:

minority children do not matter as much as non-minority children judging by the disproportionate numbers of such children who are excluded and underserved by the schools. We know, for example, that black students are placed in classes for the mildly mentally handicapped at rates more than three times those of white children. Poor children, too, are considered less important than non-poor children, if we contrast the level of financing allocated for their education with that allocated for children in more affluent districts. Non-English speaking children still face language and cultural barriers throughout America, and in many places girls still encounter lower expectations than do boys. Differential treatment of children by race, class, sex, language, and handicap subverts our nation's deepest values of fairness. Such 
treatment also has enormous practical consequences. In fact, the failure to educate millions of children is turning the potential for social profit into grave deficit, the cost of which American taxpayers will bear both financially and socially, in terms of increased dependency and the loss of a sense of common purpose..$^{54}$

Sexism is ripe and spreading in America. Women, along with particular ethnic groups, continue to be discounted as relevant moral and social agents in a society priding itself on the concepts of equality and justice. While many Americans applaud the gains by women in school and employment opportunities over the last two decades, the situation is not as promising as many would like to believe. Recent statistics reveal the following somber facts: women are less likely than men to complete four years of college; they are much less likely to continue through higher levels of education and obtain doctorates or professional degrees; at all educational levels, women have higher unemployment rates than men; women college graduates, on the average, earn less than men with an eighth-grade education; minority women earn less than any other group of workers; pregnancy is the major known cause of dropping out among school-age females; and three fifths of women at or below the poverty line are high school dropouts. ${ }^{55}$ Yet two thirds of working women are widowed, divorced, separated, have never been married, or have husbands whose annual incomes are less than $\$ 15,000$-in other words, they are the sole or major source of support for themselves and their families. ${ }^{56}$ The "feminization of poverty" is a growing problem in the United States, as women find themselves increasingly in low-wage work, and the substantial wage gap between men and women stubbornly refuses to close. ${ }^{57}$

Social problems in the United States weigh most heavily on minority groups, women, and the poor, but do not end there. Middle-class, suburban youth are also caught in a dilemma: they are children of the baby boom coming of age in a stagnating economy. Brought up in a televised world of self-interest and greed based on the principle that commodities buy happiness, and where schools are a full partner in the sales pitch, these young people experience a dilemma cogently expressed by Ralph Larkin:

(Middle-class) students experience a two-fold alienation: from adult society wherein lies the power, and from each other as invidious competition and mobility undercut authenticity and understanding of each other. They are isolated as a class and as monadic individuals. Most lives are characterized by lack of depth: in their family ties, friendships, skills, and commitment to any organizations. They live at the surface, fearful yet desirous of what might happen should they "bust out" of their not quite Edenic existence... [they] are terrorized by their fears. Their impotence and timidity generates self-hate and despair. . 58 
In other words, these students do not recognize their own selfrepression and suppression by the dominant society, and in our vitiated learning environments they are not provided with the requisite theoretical constructs to help them understand why they feel as badly as they do. Because teachers lack a critical pedagogy, these students are not provided with the ability to think critically, a skill that would enable them to better understand why their lives have been reduced to feelings of meaninglessness, randomness, and alienation and why the dominant culture tries to accommodate them to the paucity of their lives. Consequently the culture continues to run amuck, degrading the process of labor, encouraging volatile commodity consumption, and maintaining the market mechanism as the basis for the distribution of wealth and status, all of which work to impoverish the psychic life of our youth and contribute to the degradation of everyday life.

Finally, I would like to draw attention to a pressing concern of Americans both within and outside the educational system: illiteracy. In his recent book, Illiterate America, Jonathan Kozol presents us with one of the most comprehensive assessments of this crippling condition:

Twenty-five million American adults cannot read the poison warnings on a can of pesticide, a letter from their child's teacher, or the front page of a daily paper. An additional 35 million read only at a level which is less than equal to the full survival needs of our society. Together, these 60 million people represent more than one third of the entire adult population. The largest numbers of illiterate adults are white, native-born Americans. In proportion to population, however, the figures are higher for blacks and Hispanics than for whites. Sixteen percent of white adults, 44 percent of blacks, and 56 percent of Hispanic citizens are functional or marginal illiterates. Figures for the younger generation of black adults are increasing. Forty-seven percent of all black seventeen-year olds are functionally illiterate. That figure is expected to climb by 1990 .

Fifteen percent of recent graduates of urban high schools read less than sixth grade level. One million teenage children between twelve and seventeen cannot read above the third grade level. Eighty-five percent of juveniles who come before the courts are functionally illiterate. Of 8 million unemployed adults, 4 to 6 million lack the skills to be retrained for high tech jobs. The United States ranks forty-ninth among 158 member nations of the U.N. in its literacy level.59

For United States citizens besieged by the relentless logic of consumerism and privatization, it is no wonder that illiteracy thrives as a means of resisting, escaping, or refusing to be part of the cultural nightmare. What is needed to meet the crisis of literacy is a critical literacy that frames reading and writing in terms of moral and political decisionmaking. Literacy in this view is not linked to learning to read advertisements and 
becoming better consumers, or escaping into the pages of romance novels or spy thrillers; critical literacy links language competency to acquiring analytical skills which empower individuals to challenge the status quo.

It is difficult to perceive the full significance of the social crisis I have tried to portray in the preceding pages, for it demonstrates that history does not represent some linear progressive continuum headed toward equality and the steady enrichment and enhancement of human life; it is not a teleological unfolding of some metaphysical plan, the "essence" of which is material, spiritual, moral, or ethical progress. It is not the presence of linear reason in linear time but is, in fact, contingent upon particular regimes of truth operating in society. As a society, we are caught between an imminent sense of destruction and an inability to acknowledge it. The grim reality of the present situation is that the United States continues to be disfigured by class exploitation and sexual and racial inequality. Shadowed by the logic of nihilism, violence has become the purifying aesthetic to growing right-wing militant factions who wish to purge North America of blacks, Asians, Arabs, and Jews. Such xenophobia is but one of the consequences of a deteriorating society based on privilege and inequality, a society that has allowed a pathological and destructive structuring of social relations to occur. These relations have been heightened in recent years by the resurgence of fundamentalist evangelism and the revitalization trends of the New Right. In the words of Richard Sennett, "Lacking in America is any sense that the nation is a collectivity of difference, that the human community might indeed be enriched by the experience of the Other, of that which cannot be rendered transparent."60

One particularly disturbing feature of the current educational reform movement has been the appeal of the concepts of cultural literacy as advocated by E. D. Hirsch, Jr. and the literary canon as preached by Allan Bloom. Bloom espouses a view of schooling in which students are required to celebrate the so-called high-status knowledge of the Great Books of the Western World, while Hirsch argues that teachers are required to transmit the praiseworthy aspects of our American cultural heritage. ${ }^{61}$ Bloom's perspective rests on the neoclassical notion that the culture somehow "contains" knowledge (as distinct from the concept that knowledge is socially constructed), and presumably high-status knowledge is the only kind of knowledge esteemed enough to warrant inclusion in the curricula. Insistently denigrated in this view of what should be taught are the subjugated knowledges of economically disadvantaged groups, women, and minorities. Writers such as Hirsch argue that the cultural heritage of the United States should be taught, but in such a way as to conceal its socially derivative status and to cloak the selective interests that it serves in the mantle of the eternal principles of justice, equality, and fraternity. Bloom suggests that Americans would be better off if they jettisoned the search for equali- 
ty in favor of a privileged position in Plato's Republic. The position of both writers signals the rise of a repugnant new elitism.

While we fight hard not to admit it, things are not getting much better. Walter Benjamin's "angel of history" continues to gaze through clouds of despair-not to mention a disintegrated ozone layer-at a continent whose potential is greater now than ever before for unleashing worldwide catastrophe.

In an era of falling profitability and production, where each percentage point increase in the unemployment rate brings 318 additional suicides, a $2 \%$ increase in the mortality rate, a $5 \%$ to $6 \%$ increase in homicides, a 5 percent rise in imprisonments, a $3 \%$ to $4 \%$ increase in first admissions to mental hospitals, and a $5 \%$ to $6 \%$ increase in infant mortality rates, consumer culture grabs at the grotesque and the decadent. ${ }^{62}$ Images of garish and vulgar commodities litter both print and electronic media, creating an ethos of possessive and atomistic individualism, debilitating privatization, and self-seeking careerism that shunts aside the imperative to analyze existing social conditions and oppressive relations of power and privilege and to eliminate exploitation. Instead, these images reinforce a consumerist ideology characterized by the belief that the quality of everyday life is irrevocably enhanced through the continual creation of material wealth. Silicon Valley's apostles of technology and efficiency, backed by Sun Belt entrepreneurs, parade their wares as functional imperatives for modern survival, while questions of social justice and human struggle seem more and more peripheral to the commodity culture. Failing to consider how our dreams, desires, and actions have been manufactured and socially conditioned, we remain instead in the thrall of consumerist ethics. We are living collectively the American nightmare, Death of a Salesman, and like Willy Loman we are realizing that the exchange value of dead labor is empty hope. We seem to accept the belief that present conditions have arisen out of democratic necessity, as a prerequisite for our fetishistic quest for the best of all possible worlds. Inequality and poverty are the prices we must pay for freedom.

In reality, however, progress has become the scourge of history, an attack on human freedom, as the profound illogic of the times runs frictionless and free. Those who wish to build a society free from the din and carnage of war find it hardly comforting that many key figures in today's burgeoning New Right-including high-ranking government and military figures-harbor sweet cravings for Armageddon, use the Bible as the chronometer of history, and ascribe to a variation of "imminent rapture/ holocaust" in which the "purifying violence" of nuclear war is perceived as part of God's plan. (Of course, true believers will be instantly teleported to heaven by Jesus in the sky, just before the apocalyptic showdown. ${ }^{63}$ ) 
Rampant illiteracy, growing dropout rates among the poor, and a dramatic increase in classroom violence and despair exemplify the plight of today's students and teachers. As we fail to consider the possibility of practical political action or to exercise our abilities to intervene in the world, our dreams glide over the domain of ethics and continue to be manufactured in a culture of unchallenged consumer hype and moral destruction. Today more than ever before we need a pedagogical theory that is able to counter the New Right's excoriating attack on schooling, which argues that the moral vocabulary of critical pedagogy must be expunged as leftist or socialistic. The repeated assaults of reactionary ideologies, whether they are carried to us through school bashing, arms scandals, gunrunning diplomacy, or television preachers hungry for corporate power, have normalized greed, the right to be racist, the logic of self-interest, a desire for private gain, and a hatred for conscientious dissent. As the dark and ambivalent wings of history beat about the stage of our present era, where hope is held hostage, where justice is lashed to the altar of capital accumulation, and where the good works of our collective citizenry have been effaced by despair, we desperately need a new vision of what education should mean.

For teachers, this means that we must begin candidly and critically to face our society's complicity in the roots and structures of inequality and injustice. It means, too, that as teachers we must face our own culpability in the reproduction of inequality in our teaching, and that we must strive to develop a pedagogy equipped to provide both intellectual and moral resistance to oppression, one that extends the concept of pedagogy beyond the mere transmission of knowledge and skills and the concept of morality beyond interpersonal relations. This is what critical pedagogy is all about.

\section{Notes}

1. I should point out that Evan Meacham, then governor of Arizona (he was removed by the state legislature in 1988), is the same governor who feels "pickaninnies" is not an offensive word and whose education adviser believes that "if [a] student wants to say the world is flat, the teacher doesn't have the right to prove otherwise." David Handelman, Lisa Hendricksson, and Lynn Hirschberg, "The Hot List," Rolling Stone (May 21, 1987), 85.

2. This event originally came to my attention during a newscast on a Cincinnati television station. See "Rambo Comes to High School", Time (February 16, 1987), 31 ; the text of the officer's speech was taken from "Operation-Scare-the-Pants-Off'Em," Harper's, 274 (April 1987), 22-23.

3. "Born in the U.S.A.," Time (February 16, 1987), 31.

4. Ibid.

5. These ideas are expressed in Henry A. Giroux and Peter McLaren, "Teacher Education and the Politics of Democratic Life: Beyond the Reagan Agenda in the Era of 
'Good Times', " in C. C. Yeakey and G. S. Johnston (Eds.), Schools as Conduits: Educational Policymaking During the Reagan Years, New York: Praeger, in press.

6. Tom Mirga, "Restore Family Stability, Panel Urges," Education Week (November 19, 1986), 14, 17.

7. Giroux and McLaren, "Teacher Education."

8. I am referring here to reports that have played a major role in shaping educational policy at both the national and local levels. These include: National Commission on Excellence in Education, $A$ Nation at Risk: The Imperative for Educational Reform (Washington, DC: U.S. Government Printing Office, 1983); Task Force on Education for Economic Growth, Education Commission of the States, Action for Excellence: A Comprehensive Plan to Improve Our Nation's Schools (Denver: Education Commission of the States, 1983); Twentieth Century Fund Task Force on Federal Elementary and Secondary Education Policy, Making the Grade (New York: Twentieth Century Fund, 1983); Carnegie Corporation, Education and Economic Progress: Toward a National Education Policy (New York: Author, 1983); and Carnegie Forum on Education and the Economy (Hyattsville, MD: Author, 1986. Also considered are other recent reports on teacher education reform: National Commission on Excellence in Teacher Education, $A$ Call for Change in Teacher Education (Washington, DC: American Association of Colleges in Teacher Education, 1985); C. Emily Feistritzer, The Making of a Teacher (Washington, DC: National Center for Education Information, 1984); Tomorrow's Teachers: A Report of the Holmes Group (East Lansing, MI: Holmes Group, Inc., 1986); and Frances A. Maher and Charles H. Rathbone, "Teacher Education and Feminist Theory: Some Implications for Practice," American Journal of Education, 101 (1986), 214-235. For an analysis of many of these reports see Catherine Cornbleth, "Ritual and Rationality in Teacher Education Reform," Educational Researcher, 15 (April 1986), 5-14.

9. Joshua Cohen and Joel Rogers, On Democracy: Toward a Transformation of American Society (Middlesex and New York: Penguin Books, 1983), 24-27.

10. Ibid., 27-28. White men have a 1-in-131 chance of being murdered and white women a 1-in-369 chance; black women have a 1-in-104 chance and black men have a l-in-21 chance. See Dinesh D'Souza, "Racism in the 1980s," The World and I (March 1987), 26.

11. Cohen and Rogers, On Democracy, 28, 29. In addition, 26 states permit underage executions. "Children Who Kill," Newsweek (November 24, 1986), 93.

12. Michael W. Sherridan, "School Dropouts in Perspective," Educational Forum, 51 (Fall 1986), 18.

13. Spenser Rich, "Blacks on the Bottom: For an Underclass of the Poor and Alienated, Life is Only Getting Worse," Washington Post National Weekend Edition, February 3, 1986.

14. Jon D. Hull, "Life and Death With the Gangs," Time (August 24, 1987), 21.

15. Judith Cummings, "White California Youth Gangs," New York Times (January

12, 1986), 14.

16. Cohen and Rogers, On Democracy, 24-25, 27.

17. Ibid., 29.

18. Sherridan, "School Dropouts in Perspective," 18.

19. Cohen and Rogers, On Democracy, 30.

20. James P. Wright and Julie A. Lam, "Homelessness and Low Income Housing Supply," Social Policy, 17 (Spring 1987), 48-53.

21. Jane Shapiro, "The Good War: The Coalition for the Homeless Keeps on Raising the Roof," Village Voice (July 28, 1987), 21-28.

22. "Traditional Families-A Dying Breed?," Education Week (May 14, 1986), 22. 
23. Sherridan, "School Dropouts in Perspective," 19.

24. Ann Bastian, Norm Fruchter, Marilyn Gittell, Colin Greer, and Kenneth Hoskins, Choosing Equality (Philadelphia: Temple University Press, 1986), 26.

25. See Glenna Colclough and E. M. Beck, "The American Educational Structure and the Reproduction of Social Class," Sociological Inquiry, 56 (1986), 456-476. 26. For most of the following discussion of tracking, I am indebted to Jeannie Oakes, Keeping Track: How Schools Structure Inequality, New Haven: Yale University Press, 1985.

27. The statistics immediately preceding are all drawn from Sherridan, "School Dropouts in Perspective," 16.

28. Russell W. Rumberger, "High School Dropouts: A Review of Issues and Evidence," Review of Educational Research, 57, 2 (1987), 115.

29. Bastian et al., Choosing Equality, 26.

30. Ibid., 27.

31. Ibid., 55.

32. "Today's Numbers, Tomorrow's Nation," Education Week (May 14, 1986), 14.

33. "The Patterns in our Social Fabric Are Changing," Education Week (May 14, 1986), 16.

34. Deenan Glamser and Jim Myers, "USA Marvels at Minority's Winning Way," USA Today (June 12-14, 1987), 1-2.

35. Yin Ling Leung, "Inter-Racial Violence: Conflicts of Class and Culture," The Minority Trendsetter, 1 (September-October 1987), 1-7.

36. David Brand, "The New Whiz Kids," Time (August 31, 1987), 49.

37. Education Week (May 14, 1986), 16.

38. See the research presented by Samuel Bowles and Herbert Gintis, Schooling in Capitalist America: Educational Reform and the Contradictions of Economic Reform, New York: Basic Books, 1976.

39. Education Week (May 14, 1986), 16.

40. Rexford Brown, "State Responsibility for At-Risk Youth," Metropolitan Education, 2 (Fall 1986), 5-12.

41. National Coalition of Advocates for Students, Barriers to Excellence: Our Children at Risk (Boston, 1985), 10.

42. This insight was offered to me by Jim Giarelli, in personal correspondence.

43. Make Something Happen: Hispanics and Urban High School Reform (New York: Hispanic Policy Development Project, 1984), 1, 10.

44. Brown, "State Responsibility for At-Risk Youth," 6.

45. Children's Defense Fund, Black and White Children in America: Key Facts. (Washington, DC, 1985), 3.

46. Ibid., 7, 12, 60, 89.

47. Ezra Bowen, "Wrong Message from Academe," Time (April 6, 1987), 57-58.

48. Ibid.

49. Elizabeth L. Ihle, Black Women's Academic Education in the South: Modules III and IV (U.S. Department of Education and the Women's Educational Equity Act Program, 1986), 10.

50. William Proefriedt, "Education and Moral Purpose: The Dream Recovered," Teacher's College Record, 86 (1985), 399-410.

51. National Coalition of Advocates for Students, Barriers to Excellence, 5.

52. Bastian et al., Choosing Equality, 138-139.

53. National Coalition of Advocates for Students, Barriers to Excellence, 16.

54. Ibid., viii-ix. 
55. Ibid., 13.

56. Kathleen Christensen, "Women and Contingent Work," Social Policy, 17 (Spring 1987), 16.

57. Gertrude S. Goldberg and Eleanor Kremen, "The Feminization of Poverty: Only in America?", Social Policy, 17 (Spring 1987), 3-14.

58. Ralph W. Larkin, Suburban Youth in Cultural Crisis (New York: Oxford University Press, 1979), 210.

59. Jonathan Kozol, Illiterate America (Garden City, NY: Anchor, 1985), 4-5.

60. Richard Sennett, "A Republic of Souls," Harper's (July 1987), 44.

61. See E. D. Hirsch, Jr., Cultural Literacy: What Every American Needs to Know, Boston: Houghton Mifflin Co., 1987. See also Allan Bloom, The Closing of the American Mind, New York: Simon \& Schuster, 1987.

62. Cohen and Rogers, On Democracy, 29.

63. Lawrence Jones and Gerald Sheppard, "On Reagan, Prophecy, and Nuclear War," Old Westbury Review, 2 (Fall 1986), 9-22. 